time for the average "unit" is 12 hours. Furthermore, these 12 hours must be completed, on the average, in one week since the course is a half-credit. This, for a part-time student, means a minimum of two hours daily study after normal work for the whole of the academic year. It is also a second level half-course. It was the committee's considered opinion that this is an impossible task if understanding at a university level is aimed at. In their experience, the course, as it stands, would be a demanding one for fulltime students having no second halfcredit to cope with and enjoying much greater academic support than Open University students. The committee suggested that the university should cut the course in half or offer two alternative (half-) courses.

In spite of the original remit to write a course which is suitable for other than Open University students, the Consultative Committee has not been presented with any evidence that this problem has been seriously considered. One of the principal claims for obtaining support from the Nuffield Foundation was that it was not a purely Open University exercise but that other institutions would benefit equally. It is extremely doubtful if this objective is in any way near realisation. (One of the obvious deficiencies of the course soon to be offered for general sale is that the practical manual that students at universities other than the Open University will need has not been published, or even written.)

The Consultative Committee jointly with the Nuffield Foundation suggested a number of changes which would have gone some way to meet these criticisms, but they were not accepted by Professor Rose.

It is not appropriate to comment at length about the many doubts and criticisms which the committee had both about the nature of some of the units and the manner in which the course was produced. Suffice it to say that it is the opinion of the committee that the adherence to a timetable, set down before the magnitude of the problem was appreciated, made it almost mandatory that no fundamental thinking could inform the writing of the course. We have sadly come to the conclusion that a great opportunity has been lost in making use of the generous provision of the Nuffield Foundation.

Yours faithfully,

$$
\text { H. KACSER }
$$

Department of Genetics,

University of Edinburgh

R. H. Pritchard

School of Biological Sciences,

University of Leicester

J. Sano

School of Biological Sciences,

University of Sussex, UK

\section{Birds on the Chagos Bank}

SIR,-The Great Chagos Bank, $6^{\circ} 15^{\prime} \mathrm{S}$, $72^{\circ} \mathrm{E}$ is all that remains of a once gigantic atoll. The dry land now consists of eight small islands set on the rim of the atoll and an outlying group of six other islands collectively called Egmont. Together they constitute a terrestrial habitat of only 828 ha, of which Eagle and Egmont Islands make up $80 \%$.

Records indicate that at some time between 1813 and 1937 all the islands came under the influence of the copra industry. Only Nelson island was left in its "natural" state which included colonies of nesting sea birds, the eggs of which were collected to supplement the diet of the copra workers on the nearby Salamon group.

Recent surveys show that:

- on all the islands broad-leaved forest is beginning to replace the coconut plantations;

- on all islands other than Eagle and Egmont there are large populations of nesting sea-birds, numbering in total more than 100,000 pairs-dominantly terns and boobies, but including 15 species in all;

- on Eagle and Egmont there are feral brown rats and only a few hundred birds; the vegetation is, however, similar to that of the other islands.

In order to realise the full potential of the island group to nesting seabirds we suggest the removal of the rats from Egmont and Eagle Islands using a combination of methods such as "warfarin" and Liverpool virus. The islands are remote from any large centre of population and are rarely visited. Such action could allow the already overcrowded bird colonies on the local islands to expand and new species to move in from further afield. For instance, pairs of Abbots Booby were seen in the vicinity of the islands on two occasions. This is the rarest of the Indian Ocean's gannets, whose only contemporary nest site on Christmas Island is threatened by development and ecological change.

We estimate that if such action were successful the total nesting population of birds in the area could rise to in excess of 0.5 million pairs.

We are planning, subject to legislative approval, to attempt to exterminate the rats on Egmont and Eagle Islands in early 1977. We invite comment on the desirability and feasibility of this course of action.

Yours faithfully,

$$
\text { M. J. Hirons }
$$

College of Education,

Easthampstead Park, Berkshire

\section{J. Bellamy} C. SHePPARD

Department of Botany,

University of Durham, UK

\section{Bugs Bunny}

SiR,--Schedule 1 of the Conservation of Wild Creatures and Plants Act 1975, passed recently by the UK Parliament, provides the best way of giving full protection to any animal whose survival is threatened. To be included an animal must be given a common and a scientific name ("Naming the Loch Ness Monster", Nature, 258, 406; 1975). Thus, after ten years of searching, we would like to present the evidence on which we base our description and naming of the "Model E Rabbit".

The best photograph shows the head of the rabbit obscuring the DNA bands of an analytical caesium chloride gradient (below). This gradient was run in a Beckman Model E Analytical Ultracentrifuge (Wells, R., and Ingle, J., Pl. Physiol., Lancaster, 46, 178-182; 1970 ), and the rabbit must have obscured the light path while the plate was exposed.

We feel that previous failure to observe these rabbits, for surely there must be a breeding population, is due to their shy and retiring nature; the DNA on this occasion was from cucumber hypocotyls and their inordinate fondness for these may have led to this rash exposure.

In the interest of protecting this rare and endangered species we have decided to name it Oryctolagus barbifugenter because of the curious and distinctive beard-like structure characteristic of the species and because the animal so readily flees from view. It has been pointed out to us that this binomial is an anagram of "Centrifuge laboratory bugs", but this is thought to be entirely coincidental. We hope for the support of the World Wildlife Fund in our efforts to preserve and study this unique rodent.

Yours faithfully,

M. J. PASCoe

L. Potts

Department of Botany,

University of Edinburgh,

Edinburgh, UK

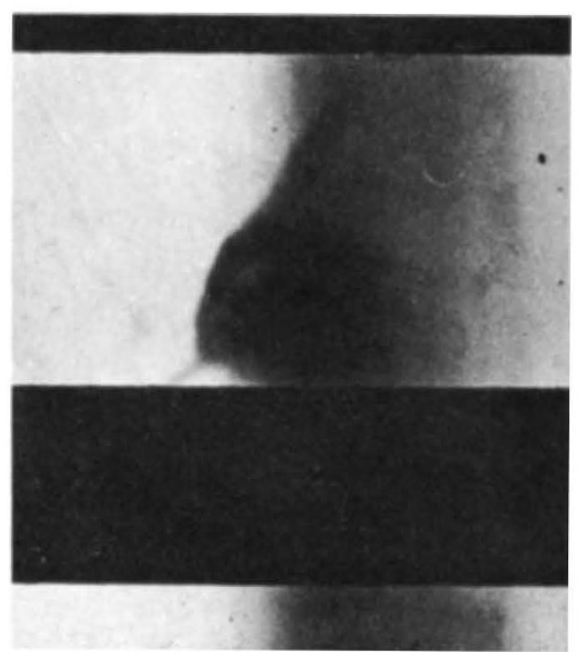

